\title{
ANALISIS ALGORITMA KNN BERBASIS FEATURE SELECTION UNTUK MEMPREDIKSI NASABAH PENGGUNA DEPOSITO MELALUI PEMASARAN LANGSUNG
}

\author{
Ami Rahmawati ${ }^{1}$, Ita Yulianti ${ }^{2}$, Yuri Yuliani ${ }^{3}$, Nurhadianto ${ }^{4}$, Hafifah Bella Novitasari ${ }^{5}$ \\ 1,2,3 Universitas Bina Sarana Infromatika \\ 4,5 STMIK Nusa Mandiri \\ E-mail: ami.amv@bsi.ac.id¹, ita.iyi@bsi.ac.id², yuri.yyi@bsi.ac.id³ ${ }^{3}$ dion.adiyanto@gmail.com4, \\ hafifah.bella@gmail.com ${ }^{5}$
}

\begin{abstract}
Abstraksi
Sebuah bank menggunakan teknik pemasaran langsung dalam menargetkan segmen nasabah dengan cara menghubungi nasabah tersebut untuk memenuhi tujuan tertentu. Setelah menghubungi nasabah, bank mendapatkan informasi apakah nasabah tersebut sudah berlangganan produk yang ditawarkan oleh bank atau belum. Salah satu produk yang ditawarkan oleh bank antara lain yaitu deposito. Dari banyaknya informasi nasabah yang dikumpulkan, bank mampu menawarkan produk dan layanan kepada nasabah. Kemampuan tersebut dapat menggunakan teknologi data mining, seperti tujuan dibuatnya penelitian ini yaitu memprediksi nasabah yang berlangganan deposito dengan algoritma K-Nearest Neighbor (KNN) dan feature selection yang diproses menggunakan tools Anaconda dan bahasa pemrograman python. Dari hasil penelitian yang diperoleh, akurasi dari penggunaan algoritma $K$-Nearest Neighbor (KNN) sebesar $74,37 \%$ dengan nilai $\mathrm{K}=9$, sedangkan akurasi algoritma klasifikasi $K$-Nearest Neighbor dengan menggunakan feature selection sebesar $89,72 \%$ dengan nilai $\mathrm{K}=3$, sehingga didapat selisih peningkatan akurasi sebesar $15,35 \%$.

Kata Kunci : Anaconda, Bank Marketing, KNN, Python
\end{abstract}

\begin{abstract}
A bank uses direct marketing techniques to target customer segments by contacting these customers to meet certain objectives. After contacting the customer, the bank gets information whether the customer has subscribed to the product offered by the bank or not. One of the products offered by banks is deposit. From the large amount of customer information collected, banks are able to offer products and services to customers. This ability can use data mining technology, such as the purpose of this research that is to predict customers who subscribe to deposits with the K-Nearest Neighbor (KNN) algorithm and feature selection that is processed using Anaconda tools and the python programming language. From the research results obtained, the accuracy of using the K-Nearest Neighbor (KNN) algorithm is $74.37 \%$ with a value of $K=9$, while the accuracy of the K-Nearest Neighbor classification algorithm by using a feature selection is $89.72 \%$ with a value of $K=3$, so that the difference is obtained an increase in accuracy of $15.35 \%$.

Keywords: Anaconda, Bank Marketing, KNN, Python
\end{abstract}

\section{Pendahuluan}

Pemasaran langsung merupakan cara efektif yang digunakan oleh bank untuk mempromosikan layanan atau produk (Ruangthong \& Jaiyen, 2015). Sebuah bank menggunakan teknik pemasaran langsung dalam menargetkan segmen nasabah dengan cara menghubungi nasabah tersebut untuk memenuhi tujuan tertentu (Moro, Cortez, \& Rita, 2014). Nasabah yang terpilih oleh bank biasanya akan dihubungi melalui kontak perorangan seperti telepon seluler ataupun email sehingga bank memperoleh informasi langsung dari nasabah dengan mengetahui apakah nasabah tersebut sudah berlangganan produk yang ditawarkan oleh bank atau belum (Dhikhi, Kumar, Nadu, \& Nadu, 2018).

Salah satu produk yang ditawarkan oleh bank antara lain deposito. Deposito merupakan simpanan yang penarikannya hanya dapat dilakukan pada waktu yang telah disepakati. Minat nasabah untuk dapat berlangganan deposito pada sebuah bank masih terbilang minim. Hal ini disebabkan karena penarikan uang deposito hanya dapat dilakukan pada waktu tertentu, padahal suku 
bunga deposito lebih tinggi dibandingkan tabungan biasa (Darmawan, 2017), sehingga deposito juga dapat dijadikan sebagai sarana alternatif dalam berinvestasi (Ula, 2018) Maka dari itu pemasaran langsung kepada nasabah digunakan sebagai strategi pihak perbankan (Kosti, Miloš, Simi, \& Kosti, 2018).

Dari banyaknya informasi nasabah yang dikumpulkan, bank mampu menawarkan produk dan layanan kepada nasabah potensial berdasarkan kebutuhan mereka, kemampuan seperti itu dapat menggunakan teknologi data mining (Kalid, Khor, Ng, \& Ting, 2014). Oleh karena itu tujuan dibuatnya penelitian ini untuk memprediksi nasabah yang berlangganan deposito dengan memanfaatkan teknik data mining.

Adapun penelitian relevan yang sudah melakukan penelitian mengenai dataset bank marketing yaitu penelitian yang dilakukan oleh Sergio Moro, Paulo Cortez, Paulo Rita tentang Pendekatan berbasis data untuk memprediksi keberhasilan telemarketing bank dengan membandingkan empat metode data mining antara lain regresi logistic, decision tree (DT), neural network (NN), dan support vector machine (SVM) dengan nilai akurasi untuk regresi logistic $71,5 \%$, untuk decision tree $75,7 \%$, untuk support vector machine $76,7 \%$, dan untuk neural network $79,4 \%$ (Moro et al., 2014)

\section{Metode Penelitian}

Model CRISP-DM (Cross Industry Standard Process for Data Mining) digunakan sebagai metode penelitian dalam penelitian ini. Model tersebut terdiri business understanding, data understanding, data preparation, modeling, evaluation, dan deployment (Rusdiawan et al., 2019).

1. Tahap Business Understanding

Tahapan ini difokuskan untuk penentuan tujuan dari penelitian yaitu menerapkan metode klasifikasi data mining menggunakan algoritma K-Nearest Neighbor untuk memprediksi nasabah yang berlangganan deposito.

2. Tahap Data Understanding

Setelah penentuan tujuan dilakukan, tahapan selanjutnya yaitu proses pengumpulan, analisa dan evaluasi kualitas data pada data Bank Marketing yang dibuat oleh sebuah lembaga perbankan Portugis yang diperoleh dari $\mathrm{UCI}$ Machine Learning Repository. Data tersebut memiliki 11.162 record dengan 16 atribut predictor dan 1 atribut hasil.
Tabel 1. Atribut dan Nilai Dataset Bank Marketing

\begin{tabular}{|c|c|}
\hline Atribut & Nilai \\
\hline Age & $\begin{array}{l}\text { Usia subjek disesuaikan } \\
\text { dengan nasabah }\end{array}$ \\
\hline Job & $\begin{array}{l}\text { ('admin.','unknown','unemploye } \\
\text { d','management','housemaid','e } \\
\text { ntrepreneur','student','bl ue- } \\
\text { collar','self- } \\
\text { employed','retired','technician','s } \\
\text { ervices') }\end{array}$ \\
\hline Marital & $\begin{array}{l}\text { (categorical: } \\
\text { 'divorced','married','single') }\end{array}$ \\
\hline Education & $\begin{array}{l}\text { ('unknown','secondary','primary' } \\
\text {,tertiary') }\end{array}$ \\
\hline Default & $\begin{array}{l}\text { apakah kredit dalam default? } \\
\text { (binary: 'yes','no') }\end{array}$ \\
\hline Balance & $\begin{array}{l}\text { saldo tahunan menurut rata- } \\
\text { rata }\end{array}$ \\
\hline Housing & $\begin{array}{l}\text { punya pinjaman perumahan? } \\
\text { (binary: 'yes','no') }\end{array}$ \\
\hline Loan & $\begin{array}{l}\text { punya pinjaman pribadi? } \\
\text { (binary: 'yes','no') }\end{array}$ \\
\hline Contact & $\begin{array}{l}\text { jenis komunikasi kontak } \\
\text { (categorical: } \\
\text { 'unknown','telephone','cellular') }\end{array}$ \\
\hline Day & $\begin{array}{l}\text { hari kontak terakhir dalam } \\
\text { sebulan }\end{array}$ \\
\hline Month & $\begin{array}{l}\text { bulan kontak terakhir tahun ini } \\
\text { (kategori: 'jan', 'feb', 'mar', ..., } \\
\text { 'nov', 'dec') }\end{array}$ \\
\hline Duration & $\begin{array}{l}\text { durasi kontak terakhir, dalam } \\
\text { detik }\end{array}$ \\
\hline Campaign & $\begin{array}{l}\text { jumlah kontak yang dilakukan } \\
\text { selama pemasaran ini dan } \\
\text { untuk nasabah ini (termasuk } \\
\text { kontak terakhir) }\end{array}$ \\
\hline Pdays & $\begin{array}{l}\text { jumlah hari yang berlalu setelah } \\
\text { nasabah terakhir dihubungi dari } \\
\text { pemasaran sebelumnya (- } 1 \\
\text { berarti klien sebelumnya tidak } \\
\text { dihubungi) }\end{array}$ \\
\hline Previous & $\begin{array}{l}\text { jumlah kontak yang dilakukan } \\
\text { sebelum pemasaran ini dan } \\
\text { untuk nasabah ini }\end{array}$ \\
\hline Poutcome & $\begin{array}{l}\text { hasil dari pemasaran } \\
\text { sebelumnya } \\
\text { (categorical:'unknown','other','fa } \\
\text { ilure','success') }\end{array}$ \\
\hline Deposit & $\begin{array}{l}\text { Variabel output (binary: } \\
\text { 'yes','no') }\end{array}$ \\
\hline
\end{tabular}

3. Tahap Data Preparation

Pada tahap Data Preparation dilakukan pengolahan data Bank Marketing, jumlah data yang diperoleh pada penelitian ini sebanyak 11.162 record, yang terdiri dari nasabah yang sudah dan tidak berlangganan deposit. Akan tetapi data 
tersebut masih terdapat data anomali, oleh karena itu sebelum melakukan pemodelan perlu dilakukan data preparation yang mana dilakukan pengecekan data kosong dan duplikat data, melakukan scaling feature, serta melakukan normalisasi data dengan mengkonversi seluruh data menjadi numerik (Hadi, 2017).

4. Tahap Modelling

Tahap ini dilakukan setelah melakukan data preparation, yaitu melakukan pemodelan dengan tools anaconda dan bahasa pemrograman python menggunakan metode klasifikasi algoritma K-Nearest Neighbor dan feature selection serta 10 fold cross validation pada data testing dan data training.

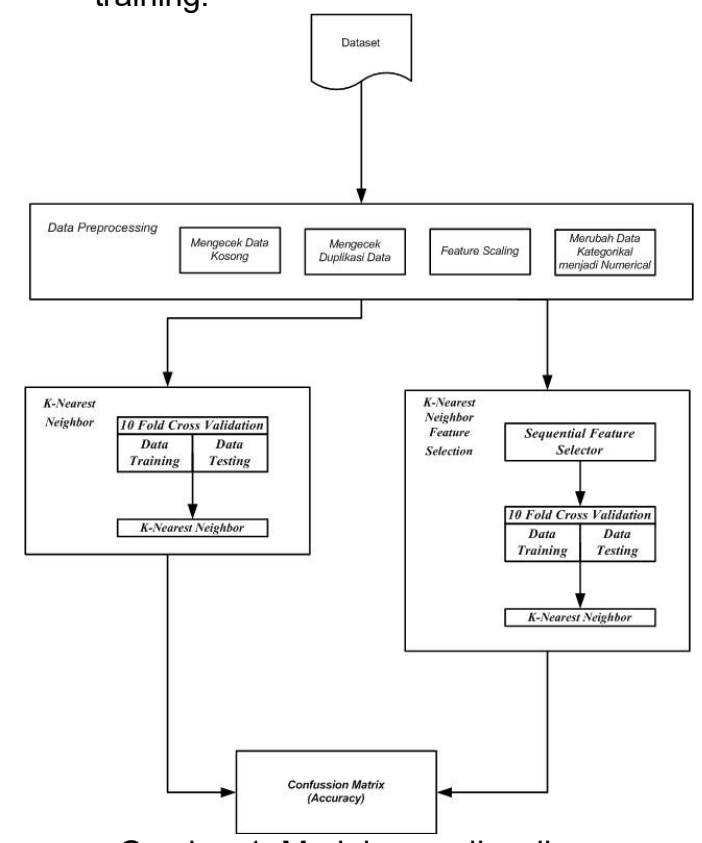

Gambar 1. Model yang diusulkan

5. Tahap Evaluation

Tahap ini melakukan evaluasi terhadap model-model yang telah terbentuk dengan menggunakan metode Confusion Matrix sehingga mendapatkan informasi model yang akurat.

6. Tahap Deployment

Dari model yang telah dihasilkan maka perlu diuji dengan menggunakan data baru dan dilakukan kembali evaluasi untuk keakuratan data.

\section{Hasil dan Pembahasan 3.1. Dataset}

Dataset yang digunakan dalam penelitian ini adalah dataset Bank Marketing. Pengolahan data menggunakan bahasa pemrograman python.

\subsection{Data Preprocessing}

\section{A. Mengecek Data Kosong}

Dalam tahap preprocessing untuk menangani data kosong pada dataset Bank Marketing dengan memasukan perintah isna.

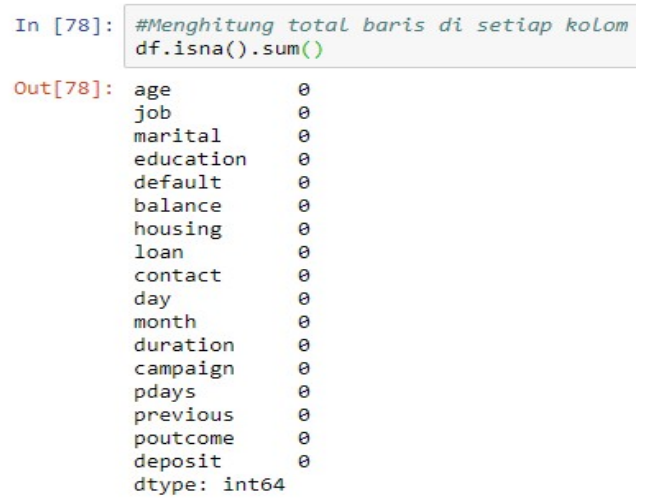

Gambar 2. Mengecek Data Kosong pada Dataset

Dalam dataset Bank Marketing semua atribut bernilai kosong yang berarti dalam data tersebut tidak memiliki data kosong.

B. Mengecek Duplikasi Data

Langkah preprocessing selanjutnya adalah mengecek duplikasi data dengan memasukkan perintah menghitung jumlah record duplikat.

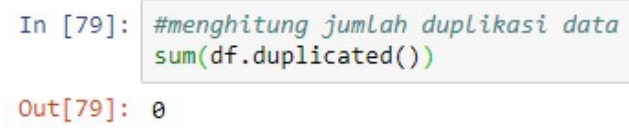

Gambar 3. Mengecek Duplikasi Data pada Dataset

Hasil yang didapatkan adalah data tersebut tidak memiliki duplikasi data.

\section{Feature Scaling}

Feature Scaling adalah suatu cara untuk membuat data numerik pada dataset supaya memiliki jangkauan nilai (scale) yang sama. Dalam penelitian ini feature scaling yang digunakan adalah standard scaler untuk menghindari salah satu atribut yang mendominasi.

D. Konversi Data Kategorikal menjadi Numerik

Pada dataset Bank Marketing terdapat beberapa type atribut yang kategorikal. Dalam 
pengolahan menggunakan python, data kategorikal harus dikonversi kedalam data numerik baik integer maupun float agar dapat diproses.

\begin{tabular}{|c|c|c|}
\hline In [89]: & print (X.dt & es) \\
\hline & age & float 64 \\
\hline & job & float 64 \\
\hline & marital & float 64 \\
\hline & education & float 64 \\
\hline & default & float 64 \\
\hline & balance & float 64 \\
\hline & housing & float 64 \\
\hline & loan & float 64 \\
\hline & contact & float 64 \\
\hline & day & float 64 \\
\hline & month & float 64 \\
\hline & duration & float 64 \\
\hline & campaign & float 64 \\
\hline & pdays & float 64 \\
\hline & previous & float 64 \\
\hline & poutcome & float 64 \\
\hline & dtype: ob & \\
\hline
\end{tabular}

Gambar 4. Merubah Data Kategorikal menjadi Numerik

\subsection{Explorasi Data}

Langkah explorasi data dilakukan untuk mendapatkan informasi-informasi dan memahami dataset tersebut. Explorasi data yang dilakukan dengan menampilkan berbagai informasi atribut dalam bentuk grafik seperti berikut:

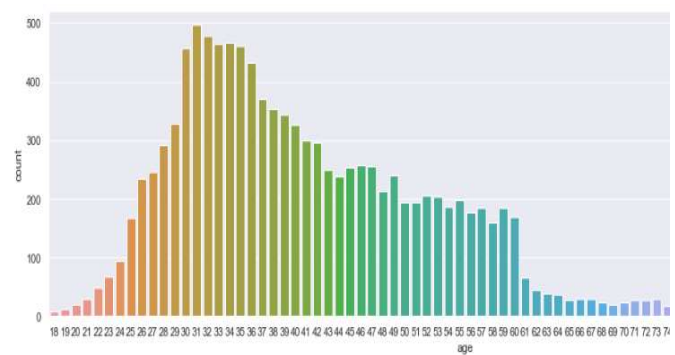

Gambar 5. Usia Nasabah pada Dataset Bank Marketing

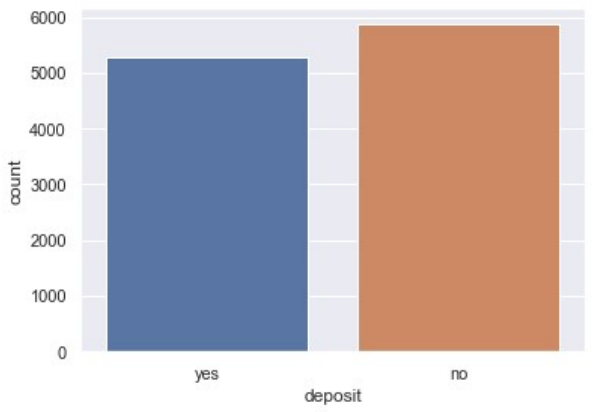

Gambar 6. Perbandingan Class Nasabah Deposit

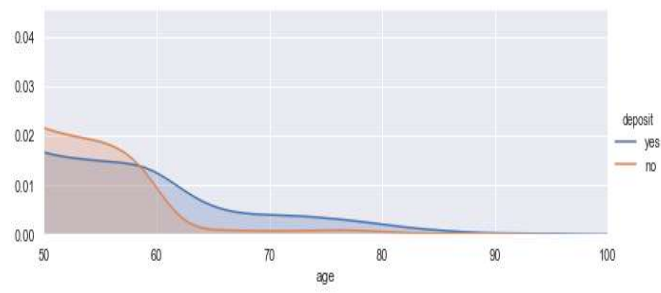

Gambar 7. Perbandingan Usia Nasabah terhadap data yang berlangganan deposit

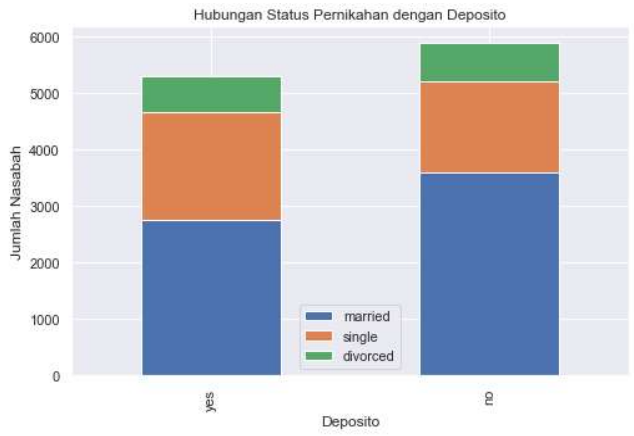

Gambar 8. Hubungan antara Status Pernikahan dengan Class Deposito

Status Pinjaman Pribadi

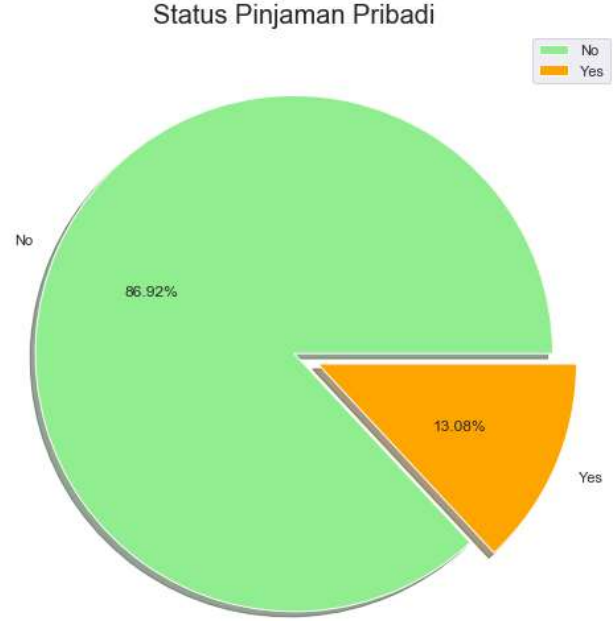

Gambar 9. Persentase Status Pinjaman Pribadi pada Dataset Bank Marketing

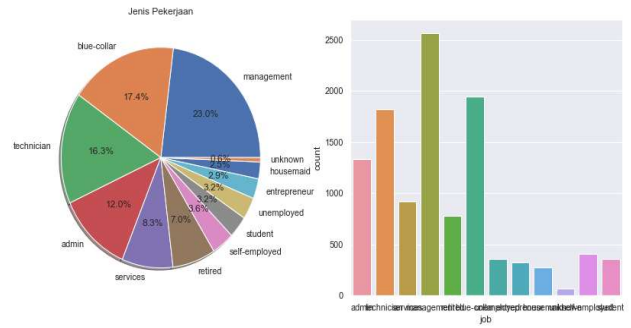

Gambar 10. Persentase Jenis Pekerjaan pada Dataset Bank Marketing 
3.4. Klasifikasi K-Nearest Neighbor

Tahap klasifikasi dilakukan dengan algoritma K-Nearest Neighbor dengan menggunakan $k$-fold Cross Validation. Terlebih dahulu menentukan variable target dan variable predictor.

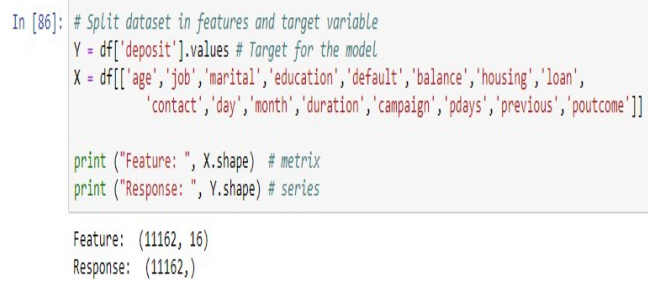

Gambar 11. Menentukan Variabel Taget dan Variabel Predictor

Kemudian menginput perintah $k$-Fold Cross Validation dengan nilai fold sebanyak 10 kali dengan nilai $\mathrm{K}=3, \mathrm{~K}=5, \mathrm{~K}=7, \mathrm{~K}=9$. Setelah dilakukan pengujian maka diperoleh hasil sebagai berikut :

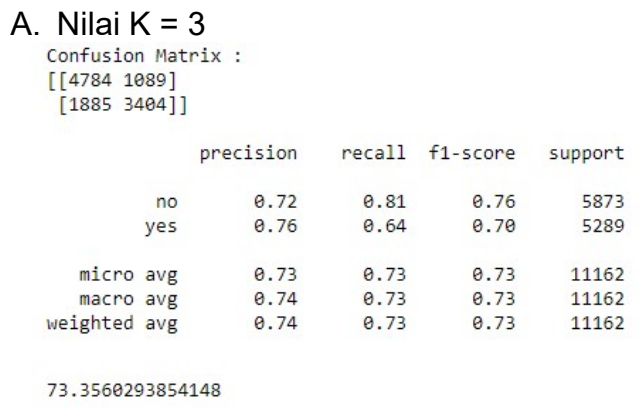

Gambar 12. Hasil Akurasi dengan Nilai $\mathrm{K}=3$

Nilai akurasi yang didapat dengan menggunakan algoritma K-Nearest Neighbor sebesar $73,35 \%$, dengan jumlah True Positive sebanyak 4.784 data, False Positive sebanyak 1.089 data, True Negative sebanyak 3.404 data, dan False Negative sebanyak 1.885 data.

B. Nilai $K=5$

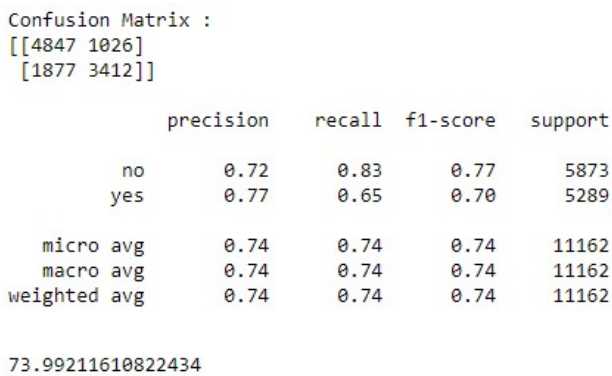

Gambar 13. Hasil Akurasi dengan Nilai $\mathrm{K}=3$
Nilai akurasi yang didapat dengan menggunakan algoritma K-Nearest Neighbor sebesar $73,99 \%$, dengan jumlah True Positive sebanyak 4.784 data, False Positive sebanyak 1.026 data, True Negative sebanyak 3.412 data, dan False Negative sebanyak 1.877 data.

C. Nilai $\mathrm{K}=7$

Confusion Matrix :

[ [ $\left[\begin{array}{cc}4859 & 1014\end{array}\right]$

$\left[\begin{array}{ll}1881 & 3408\end{array}\right]$

$\begin{array}{rrrrr} & \text { precision } & \text { recall } & \text { f1-score } & \text { support } \\ \text { no } & 0.72 & 0.83 & 0.77 & 5873 \\ \text { yes } & 0.77 & 0.64 & 0.70 & 5289 \\ & & & & \\ \text { micro avg } & 0.74 & 0.74 & 0.74 & 11162 \\ \text { macro avg } & 0.75 & 0.74 & 0.74 & 11162 \\ \text { weighted avg } & 0.74 & 0.74 & 0.74 & 11162\end{array}$

74.06378785163949

Gambar 14. Hasil Akurasi dengan Nilai K $=7$

Nilai akurasi yang didapat dengan menggunakan algoritma K-Nearest Neighbor sebesar 74, 06\%, dengan jumlah True Positive sebanyak 4.859 data, False Positive sebanyak 1.014 data, True Negative sebanyak 3.408 data, dan False Negative sebanyak 1.881 data.

D. Nilai $K=9$

Confusion Matrix :

[ [ 48871 1002]

$\left[\begin{array}{ll}1858 & 3431\end{array}\right]$

$\begin{array}{rrrrr} & \text { precision } & \text { recall } & \text { f1-score } & \text { support } \\ \text { no } & 0.72 & 0.83 & 0.77 & 5873 \\ \text { yes } & 0.77 & 0.65 & 0.71 & 5289 \\ \text { micro avg } & 0.74 & 0.74 & 0.74 & 11162 \\ \text { macro avg } & 0.75 & 0.74 & 0.74 & 11162 \\ \text { weighted avg } & 0.75 & 0.74 & 0.74 & 11162 \\ & & & & \\ \text { 74.37735172908081 } & & & & \end{array}$

Gambar 15. Hasil Akurasi dengan Nilai K = 9

Nilai akurasi yang didapat dengan menggunakan algoritma K-Nearest Neighbor sebesar 74, 37\%, dengan jumlah True Positive sebanyak 4.871 data, False Positive sebanyak 1.002 data, True Negative sebanyak 3.431 data, dan False Negative sebanyak 1.858 data.

Selanjutnya dilakukan pengujian dengan menggunakan feature selection dengan $k$-fold Cross Validation dengan nilai fold sebanyak 10 kali dengan nilai $K=3, K=5, K=7, K=9$. Setelah dilakukan pengujian maka didapat hasil sebagai berikut : 
A. Nilai $\mathrm{K}=3$

confusion matrix :

$\left[\begin{array}{ll}5212 & 661\end{array}\right]$

[ 486 4803] ]

precision recall f1-score support

$\begin{array}{rllll}\text { no } & 0.91 & 0.89 & 0.90 & 5873 \\ \text { yes } & 0.88 & 0.91 & 0.89 & 5289 \\ & & & & \\ \text { micro avg } & 0.90 & 0.90 & 0.90 & 11162 \\ \text { macro avg } & 0.90 & 0.90 & 0.90 & 11162 \\ \text { weighted avg } & 0.90 & 0.90 & 0.90 & 11162\end{array}$

89.72406378785163

Gambar 16. Hasil Akurasi dengan Nilai K = 3

Nilai akurasi yang didapat dengan menggunakan algoritma K-Nearest Neighbor dengan feature selection sebesar $89,72 \%$, dengan jumlah True Positive sebanyak 5.212 data, False Positive sebanyak 661 data, True Negative sebanyak 4.803 data, dan False Negative sebanyak 486 data.

B. Nilai $\mathrm{K}=5$

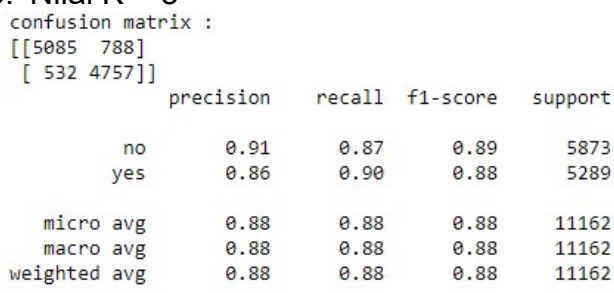

88.17416233649884

Gambar 17. Hasil Akurasi dengan Nilai K = 3

Nilai akurasi yang didapat dengan menggunakan algoritma K-Nearest Neighbor dengan feature selection sebesar $88,17 \%$, dengan jumlah True Positive sebanyak 5.085 data, False Positive sebanyak 788 data, True Negative sebanyak 4.757 data, dan False Negative sebanyak 532 data.

C. Nilai $\mathrm{K}=7$

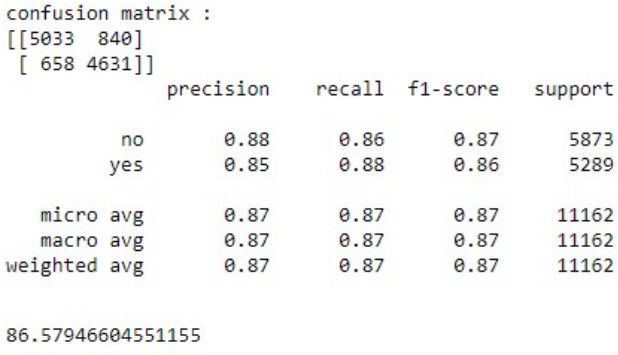

Gambar 18. Hasil Akurasi dengan Nilai $\mathrm{K}=7$

Nilai akurasi yang didapat dengan menggunakan algoritma K-Nearest Neighbor dengan feature selection sebesar $86,57 \%$, dengan jumlah True Positive sebanyak 5.033 data, False Positive sebanyak 840 data, True Negative sebanyak 4.631 data, dan False Negative sebanyak 658 data.

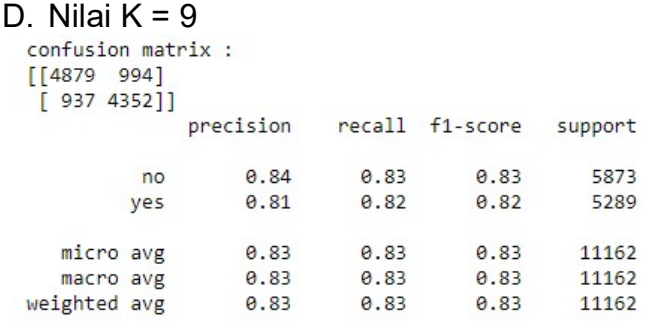

82.70023293316609

Gambar 19. Hasil Akurasi dengan Nilai K = 9

Nilai akurasi yang didapat dengan menggunakan algoritma K-Nearest Neighbor dengan feature selection sebesar $82,70 \%$, dengan jumlah True Positive sebanyak 4.879 data, False Positive sebanyak 994 data, True Negative sebanyak 4.352 data, dan False Negative sebanyak 937 data.

Nilai akurasi yang terbesar diperoleh menggunakan menggunakan algoritma $K$ Nearest Neighbor dengan feature selection pada nilai $\mathrm{K}=3$ dengan nilai akurasi $89,72 \%$.

Perhitungan evaluasi algoritma K-Nearest Neighbor dengan confusion matrix pada dataset Bank Marketing sebagai berikut:

Tabel 2. Confusion Matrix K-Nearest Neighbor Dataset Bank Marketing

\begin{tabular}{|c|c|c|}
\hline \multirow{2}{*}{ Class } & \multicolumn{2}{|c|}{ Diklasifikasikan sebagai } \\
\cline { 2 - 3 } & Yes & No \\
\hline Yes & $4871(\mathrm{TP})$ & $1002(\mathrm{FP})$ \\
No & $1858(\mathrm{FN})$ & $3431(\mathrm{TN})$ \\
\hline
\end{tabular}

Berdasarkan confusion matrix pada tabel 1 dari 1116 data Bank Marketing diketahui sebanyak 4871 data positif diklasifikasikan sebagai positif dan sebanyak 3431 data negatif diklasifikasikan sebagai negatif. Sedangkan sebanyak 1002 data positif diklasifikasikan sebagai negatif dan sebanyak 1858 data negatif diklasifikasikan sebagai positif. Berikut merupakan perhitungan nilai accuracy:

Accuracy $=\frac{4871+3431}{4871+1858+1002+3431} \times 100 \%=74,37 \%$

Perhitungan evaluasi algoritma $K$-Nearest Neighbor Feature Selection dengan confusion 
matrix pada dataset Bank Marketing sebagai berikut:

Tabel 3. Confusion Matrix K-Nearest Neighbor Feature Selection Dataset Bank Marketing

\begin{tabular}{|c|c|c|}
\hline \multirow{2}{*}{ Class } & \multicolumn{2}{|c|}{ Diklasifikasikan sebagai } \\
\cline { 2 - 3 } & Yes & No \\
\hline Yes & $5212(\mathrm{TP})$ & $661(\mathrm{FP})$ \\
No & $486(\mathrm{FN})$ & $4803(\mathrm{TN})$ \\
\hline
\end{tabular}

Berdasarkan confusion matrix pada tabel 2 dari 1.116 data Bank Marketing diketahui sebanyak 5.212 data positif diklasifikasikan sebagai positif dan sebanyak 4.803 data negatif diklasifikasikan sebagai negatif. Sedangkan sebanyak 661 data positif diklasifikasikan sebagai negatif dan sebanyak 486 data negatif diklasifikasikan sebagai positif. Berikut merupakan perhitungan nilai accuracy:

$$
\text { Accuracy }=\frac{5212+4803}{5212+4803+661+486} \times 100 \%=89,72 \%
$$

Tabel 4. Pengujian Algoritma K-Nearest Neighbor

\begin{tabular}{|c|c|}
\hline Nilai K & Accuracy \\
\hline K=3 & $73,35 \%$ \\
\hline K=5 & $73,99 \%$ \\
\hline K=7 & $74,06 \%$ \\
\hline K=9 & $74,37 \%$ \\
\hline
\end{tabular}

Tabel 5. Pengujian Algoritma K-Nearest Neighbor dan Feature Selection

\begin{tabular}{|c|c|}
\hline Nilai K & Accurracy \\
\hline $\mathrm{K}=3$ & $89,72 \%$ \\
\hline $\mathrm{K}=5$ & $88,17 \%$ \\
\hline $\mathrm{K}=7$ & $86,57 \%$ \\
\hline $\mathrm{K}=9$ & $82,70 \%$ \\
\hline
\end{tabular}

\section{Kesimpulan}

Dari hasil penelitian yang diperoleh, akurasi dari penggunaan algoritma klasifikasi K-Nearest Neighbor dalam prediksi Bank Marketing sebesar $74,37 \%$ dengan nilai $\mathrm{K}=9$, sedangkan untuk akurasi algoritma klasifikasi K-Nearest Neighbor dengan menggunakan feature selection sebesar $89,72 \%$ dengan nilai $\mathrm{K}=3$, sehingga didapat selisih peningkatan akurasi sebesar $15,35 \%$.

Referensi
Anam, C., \& Santoso, H. B. (2018). Perbandingan Kinerja Algoritma C4 . 5 dan Naive Bayes untuk Klasifikasi Penerima Beasiswa. 8(1), 13-19.

Ary, M. (2019). SATIN - Sains dan Teknologi Informasi Ukuran Akurasi Klasifikasi Penyakit Mesothelioma Menggunakan Algoritma K-Nearest Neighbor dan Backward Elimination. 5(1).

Bode, A. (2017). K-NEAREST NEIGHBOR DENGAN FEATURE SELECTION MENGGUNAKAN BACKWARD ELIMINATION UNTUK PREDIKSI HARGA KOMODITI KOPI ARABIKA. 9, 188-195.

Darmawan, H. (2017). pilih mana menabung di deposito bank atau menabung. Retrieved August 20, 2019, from https://www.finansialku.com/pilih-manamenabung-di-deposito-bank-ataumenabung-di-saham-bank/

Dhikhi, T., Kumar, V., Nadu, T., \& Nadu, T. (2018). Bank Marketing Analysis. 8(11), 4-9.

Hadi, A. F. (2017). ANALISIS DATA MINING UNTUK MENENTUKAN VARIABEL VARIABEL YANG MEMPENGARUHI. 4(1), 108-116.

Kalid, S. N., Khor, K. C., Ng, K. H., \& Ting, C. Y. (2014). Effective Classification for Unbalanced Bank Direct Marketing Data with Over-sampling. i(August), 12-15.

Kosti, S. M., Miloš, Đ., Simi, M. I., \& Kosti, M. V. (2018). Data Mining and Modeling Use Case in Banking Industry. 1-4.

Lestari, M. E. I. (2014). PENERAPAN ALGORITMA KLASIFIKASI NEAREST NEIGHBOR (K-NN) UNTUK MENDETEKSI PENYAKIT JANTUNG. 7(September 2010), 366-371.

Moro, S., Cortez, P., \& Rita, P. (2014). A datadriven approach to predict the success of bank telemarketing. Decision Support Systems.

https://doi.org/10.1016/j.dss.2014.03.00 1

Mustafa, M. S., \& Simpen, I. W. (n.d.). 
Implementasi Algoritma K-Nearest Neighbor ( KNN ) Untuk Memprediksi Pasien Terkena Penyakit Diabetes Pada Puskesmas Manyampa Kabupaten Bulukumba. VIII(1), 1-10.

Pengetahuan, J., \& Komputer, D. A. N. T. (2017). PENERAPAN METODE KNEAREST NEIGHBOR PADA PENENTUAN GRADE DEALER. 2(2), 108-112.

Ruangthong, P., \& Jaiyen, S. (2015). Bank Direct Marketing Analysis of Asymmetric Information Based on Machine Learning. 93-96.

Rusdiawan, T. W., Alamsyah, A., Manajemen, M., Ekonomi, F., Bisnis, D., \& Telkom, U. (2019). EKSPLORASI DATA PELANGGAN, UNTUK KONTEKSTUAL MARKETING VOICE OVER LONG TERM EVOLUTION PT. TELKOMSEL MENGGUNAKAN METODE CLUSTERING K-MEANS CUSTOMER DATA EXPLORATION , FOR CONTEXTUAL MARKETING VOICE OVER LONG TERM EVOLUTION PT. TELKOMSEL USING K-MEANS CLUSTERING METHOD. 6(1), 537-544.

Ula, R. (2018). PENGARUH CAPITAL ADEQUACY RATIO ( CAR ), INFLASI, DAN SUKU BUNGA SERTIFIKAT BANK INDONESIA ( SBI ) TERHADAP TINGKAT SUKU BUNGA DEPOSITO BERJANGKA ( Studi Pada Perusahaan Bank Pembangunan Daerah di Indonesia Periode 2010-2015 ). 56(1). 